Sheridan College

SOURCE: Sheridan Institutional Repository

\title{
$4-2013$
}

\section{Business Transformation and Innovation using Storytelling}

\author{
Ginger Grant \\ Sheridan College, ginger.grant@sheridancollege.ca
}

Follow this and additional works at: https://source.sheridancollege.ca/pilon_publ

Part of the Business Commons

\section{SOURCE Citation}

Grant, Ginger, "Business Transformation and Innovation using Storytelling" (2013). Publications and Scholarship. 6.

https://source.sheridancollege.ca/pilon_publ/6

\section{(c) $(1) \Theta \Theta$}

This work is licensed under a Creative Commons Attribution-Noncommercial-No Derivative Works 4.0 License. This Conference Proceeding is brought to you for free and open access by the Pilon School of Business at SOURCE: Sheridan Institutional Repository. It has been accepted for inclusion in Publications and Scholarship by an authorized administrator of SOURCE: Sheridan Institutional Repository. For more information, please contact source@sheridancollege.ca. 
Global Innovators Conference 2013

College of the North Atlanic-Qatar, 4-7 ${ }^{\text {th }}$ April 2013

\title{
Business Transformation and Innovation using Storytelling
}

\author{
Ginger Grant
}

Business, Mississauga Ontario,

Canada

http://dx.doi.org/10.5339/ qproc.2013.gic.6

(C) 2013 Grant, licensee Bloomsbury Qatar Foundation Journals. This is an open access article distributed under the terms of the Creative Commons Attribution license CC BY 3.0, which permits unrestricted use, distribution and reproduction in any medium, provided the original work is properly cited.

\section{Abstract}

The demand for innovation within organizations is a worldwide concern. In order for innovation to occur, creativity must first be unleashed in the individual. Education is under heavy criticism for failure to produce the workforce needed to meet the innovation challenge. The solution lies in the human imagination.

Many have tried to 'teach' creativity, which results in a prescriptive focus on tools and process, but has limited, if any, emotional engagement. Emotion is a necessary component as the creative drive is intrinsic - it originates from within. In order to increase innovation capacity in our organizations, we need to first increase creative capacity in individuals.

Further, creativity is personal; so the student dictates the context of reflection and explores the belief system that motivates exploration of the creative force. This is a constructivist approach to learning that seeks to transform the learning experience by having the student engage with their own story. 


\section{What is my purpose?}

The demand for innovation within organizations is a worldwide concern. In order for innovation to occur, creativity must first be unleashed in the individual. Education is under heavy criticism for failure to produce the workforce needed to meet the innovation challenge. The solution lies in the human imagination.

Many have tried to 'teach' creativity, which results in a prescriptive focus on tools and process, but has limited, if any, emotional engagement. Emotion is a necessary component as the creative drive is intrinsic - it originates from within. In order to increase innovation capacity in our organizations, we need to first increase creative capacity in individuals

Further, creativity is personal; so the student dictates the context of reflection and explores the belief system that motivates exploration of the creative force. This is a constructivist approach to learning that seeks to transform the learning experience by having the student engage with their own story.

\section{Why?}

The purpose of stories has always been to act as a bridge between the past and the future. It is the stories of old that carry the cultural value system into the present and on into the future, recontextualized to suit the time at hand. Why is this important now? Our mode of production has shifted to organizational knowledge creation. In this new economic environment, a traditional mode of production thinking is potentially counter-productive. A new paradigm is needed, one that recognizes that the future belongs to people who use their hearts as well as their heads. Awareness of this shift is the key to realizing a new paradigm (Grant 2005).

Using stories transforms business education and deepens the learning experiences in a current context. This featured creativity and innovation course allows students to explore their attitude and experiences about judgment, fear of change, imagination, spontaneity, and links to individual passion and purpose; a visioning of potential and possibility experienced through a 14week journey. The students discover their own balance between critical and creative thinking and it is my hope as a result that they also expand their capacity for innovation.

In the second half of the course, the students apply their personal knowledge and insight gained to an organization or corporate challenge of their choice thus linking personal creativity and organizational innovation.

A final reflection paper on the student's experience is completed and forms the basis for this ongoing qualitative study. Examples will be provided in the presentation of student reflections on their own learning throughout the course and are also included in this paper.

Learning Objectives in the Course:

- $\quad$ establishing a growth mindset

- $\quad$ enhancing creative capacity

- collaborative teamwork

- multidisciplinary problem-based learning

- developing and enhancing intrinsic motivation

- embracing failure as a learning opportunity

- $\quad$ self-discovery and reflection

- learn how to create a culture that supports innovation.

\section{Why am I interested?}

What use are stories? Why are they important? How does storytelling fit in the cut-and-dried arena of business? In my previous life as a specialist in competitive intelligence and due diligence, I noticed that an incredible amount of time and effort was spent in the financial and legal analysis of public offerings; but little emphasis was placed on the analysis of corporate culture of the organizations involved. Yet, culture played a key role in the stories told on the various international stock exchanges; the stories of leaders, of corporate histories, of mergers and acquisitions, and of the many failures in pubic offerings. 
These questions and my frustration with lack of answers were the starting place for my journey into graduate education. My world now is both the world of organizations and my ongoing fascination with the transformative power of archetypal psychology. The bridge I use to move between the two worlds is storytelling

Joseph Campbell was a founding member and advisor of the school where I did my graduate studies. Campbell believed that there was a myth that crossed all cultural barriers; all age groups, gender and race. He called it a monomyth and described it in his seminal work, The Hero with a Thousand Faces. Some North Americans were introduced to Campbell and his work in a PBS Special on the Power of Myth. Many others were introduced to Campbell by one of his protégées, George Lucas in a series of movie epic adventures called "Star Wars". Campbell claimed that the story of the hero is as old as time itself; understanding that the story of the hero is one that all individuals follow, since, aware or not, the Heroic Path can and does mirror a journey through life. My interest in Campbell's work is a practical one, for I have found no other model that provides easy access to the world of change. The Heroic Journey provides both a common language to be used and a map of the territory to be explored. Regardless of age, participants in both university courses and executive education workshops and seminars can find their story within the model. More importantly to me as an educator, participants then can find and empathize with the stories of others. Recognizing that story is both current and past allows for one to develop story as a vehicle towards a desired future.

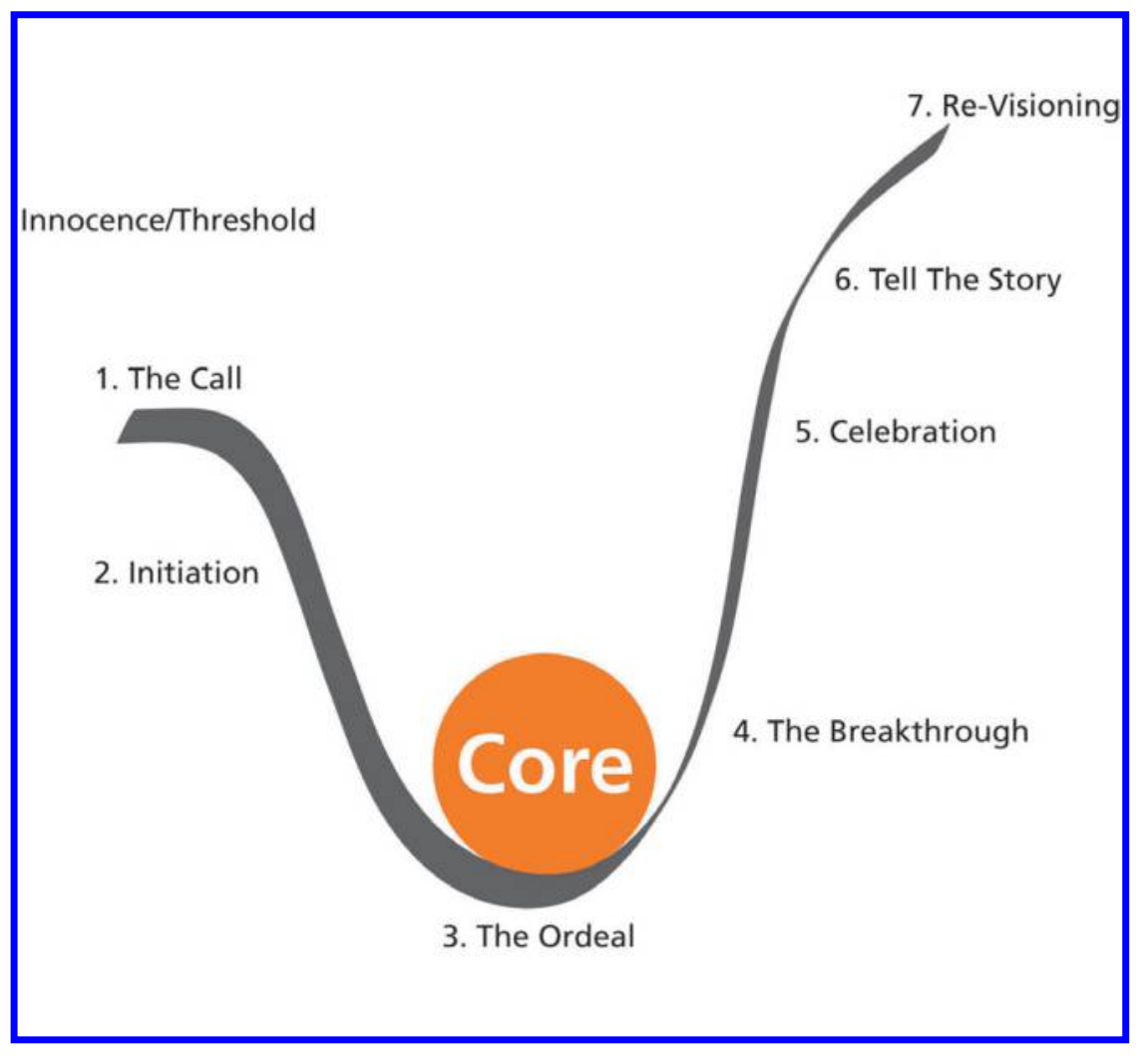

Educator Kieren Egan states that stories are unique narratives that in their basic form, provide ends that satisfy some tension generated by their beginnings (1999, p. 88). He suggests that we think of the content of curriculum as great stories to tell $(1998,2005)$. The question then becomes how to link that great story we tell to the individual student? We are constantly constructing our worldview and encourage our students to develop their own (properly socialized by our educational standards of course). The challenge arises when the old paradigm is shifting or even collapsing and the new paradigm is not yet fully formed, still emergent. How do we link the cultural development of the past (expressed in our values) and the educational needs of the present? 


\section{What if?}

Many business schools still teach that the purpose of an organization is profitability, and thus concentrate on financial measurement and return on investment. The current trend is moving towards emphasizing the individual's potential within the organization. In this more strategic model, based on human capital retention, individuation of the knowledge worker is the prime concern, and the profitability of the corporation has a secondary focus. Such an emphasis does not preclude profitability, but permits both individual and organization a path to success (Grant 2005).

In the same way that the bulk of an iceberg lies beneath the surface, forces that determine our effectiveness at work encompass those "soft", intangible factors that linear, analytical mindsets find hard to quantify and acknowledge as real. And yet without capturing emotional commitment, no lasting change can take place. Enter the proven Stanford "Creativity in Business" model - combining strategic intent with operational tactics and an economic driver.

\section{Creativity and innovation are about relationships}

Creativity in Business is a developmental process designed to leverage personal and organizational performance. It is based on the premise that organizational success depends on the individual's ability to create and sustain a positive corporate culture on a daily basis. This type of sustainable relationship building requires both character and skill and is the role of a "Change Agent" - the individual tasked with design-driven innovation. In order to move an organization away from the obsolete command-control environment, towards one of increased creativity and innovation, you must transform your organizational culture.

This involves shifting mindset, both from an individual and a organizational or team perspective. The emphasis is on the "why" of the reflective process - questioning current beliefs about creativity and innovation. Are those beliefs still valid under the current context? The answers are sometimes surprising.

\begin{tabular}{lll}
\hline Journey Quest & The Creative Individual & The Creative Organization \\
\hline Identity & Who am I? & Who are we? \\
Personality & What kind of person am I? & What kind of group is this? \\
& How do I perceive, learn, & What kind of team do I lead? \\
& Whmunicate? & How do we integrate \\
& of intelligence? & How do we handle and \\
& How do I communicate with & prevent inner conflict? \\
& others who are different? & \\
Strengths and Skills & What are my talents and & What are our core \\
& passion? & competencies? \\
& What's my unique and best & What's our unique \\
& contribution? & contribution to the \\
& & marketplace? \\
& & How will we stand out? \\
Purpose and Meaning & Why am I here? & Why have we come together? \\
& What is my legacy? & Where do we fit? \\
& How do I perceive the world & What is our shared world \\
& and my role in it? & view? \\
& What is my personal sense of & What is our legacy as leaders? \\
& purpose? my creative core? & What enriches and enlivens \\
& & me?
\end{tabular}




\begin{tabular}{|c|c|c|}
\hline Journey Quest & The Creative Individual & The Creative Organization \\
\hline Values & $\begin{array}{l}\text { What is important to me? } \\
\text { What worldview governs my } \\
\text { priorities? } \\
\text { What core values guide my } \\
\text { actions? Where are my values } \\
\text { gaps? }\end{array}$ & $\begin{array}{l}\text { How do my own values } \\
\text { align and support the } \\
\text { organizational values? } \\
\text { What do we value most as a } \\
\text { group? } \\
\text { Do these values serve our } \\
\text { purpose? } \\
\text { Are they in alignment } \\
\text { with the values of various } \\
\text { stakeholders? }\end{array}$ \\
\hline Principles and Practice & $\begin{array}{l}\text { Do I behave in accordance } \\
\text { with my values, purpose and } \\
\text { sense of meaning? } \\
\text { Do I allocate my resources } \\
\text { of time and attention in } \\
\text { accordance with my values? }\end{array}$ & $\begin{array}{l}\text { How do the policies, practices } \\
\text { and performance of the } \\
\text { organization reflect our } \\
\text { values, purpose and sense of } \\
\text { meaning? } \\
\text { How do we allocate } \\
\text { resources? }\end{array}$ \\
\hline Experience & $\begin{array}{l}\text { What stories do I tell about } \\
\text { myself and my experience? } \\
\text { What value is derived from } \\
\text { these stories? }\end{array}$ & $\begin{array}{l}\text { What myths and stories do we } \\
\text { share about our organization? } \\
\text { Why are they considered } \\
\text { meaningful? } \\
\text { What reaction do they elicit? }\end{array}$ \\
\hline Image and Corporate & $\begin{array}{l}\text { How do I project myself to } \\
\text { others? } \\
\text { How do I think I am perceived? } \\
\text { Are my self-image and my } \\
\text { public-image aligned? }\end{array}$ & $\begin{array}{l}\text { What is our brand? } \\
\text { Do we brand from the inside } \\
\text { out? } \\
\text { Do we 'walk our talk'? }\end{array}$ \\
\hline
\end{tabular}

\section{Methods of inquiry}

The overall objective of this phenomenological research project is to obtain exploratory data to better understand Adventure Learning (AL) course delivery in higher education, as well as experiential impact on students. This is a five-year longitudinal study commencing January 2013 and ending in December 2017. As our sample size is limited, a longitudinal study will allow us to access themes across a larger sample size. The longitudinal format will permit the collection of student stories so that potential themes may be realized from any patterns that develop.

Students will be asked to respond to reflective questions as part of their course requirements. All identifying characteristics of the students contained in the responses will be removed. Students have the potential to reveal more than they originally intended. They will be reminded to only reveal what they are comfortable speaking in front of the class. Students will be reminded of the principles of confidentiality and helping to create a safe working environment to allow creativity to emerge.

Personal information that will be collected from the participants of this applied research project will include

- Demographic information. Students will be asked to complete a very short demographic questionnaire that will include questions about gender, age, ethnicity, mother tongue, country of origin, date of arrival in Canada, and highest credential prior to coming to Sheridan and location of the issuing institution. Such information will be collected in order to discover any meaningful patterns in the data.

- Handling of personal information: Any identifying information (name) about each student will not be used for purposes of analysis and publication. Once data has collected a numerical code will be assigned to each participant. A code book linking the students with their assigned numerical code will be kept in a locked cabinet in the office of the 
Professor. The code book of participant names will be kept in a locked cabinet for a period of five years, at which time the information will be destroyed.

- Participants. Male and female students from the Business Administration Accounting, Finance, Human Resources or Marketing Diploma Programs enrolled in the Applied Creativity and Innovation (BUSM24310) course at Sheridan College.

- Recruitment procedure. Students will be recruited in class. Information about this pilot study will be disseminated by way of information sheets. Details about the study and its importance to post-secondary teaching and learning scholarship will be conveyed to potential participants. Release forms will be distributed at the session to collect contact details and consent indicating their willingness to participate in this study. Participation is completely voluntary.

Selection criteria. All students enrolled in the Applied Creativity and Innovation (MGMT2410) course are eligible to participate in this study.

Exclusion criteria. None. Students who choose not to participate will be excluded without penalty. If students decide to participate, they may withdraw at any time without any consequences or any explanation. If they do withdraw from the study, their data will be withheld from the findings.

Reflective assignments and questions will be posed to students throughout a 14-week course. The qualitative date for this phenomenological research project will be collected these reflective assignments

Phenomenological inquiry. Phenomenology involves the exploration of human experience though conscious, retrospective reflection. Phenomenological inquiry seeks to examine, understand and interpret observable special events in our everyday life, with the benefit of sharing the meaning of these phenomena with others. Experiences are individual constructions illustrating the essence of an event, embedded into a particular context influencing or affecting experiences and psychological states. For example, within the Creativity and Innovation course, how do participants experience personal creativity, leadership, followership or conflict? In this instance creativity, leadership, followership or conflict is the phenomenon of interest, but is a psychological abstraction. For example, what do you experience when you face conflict in teams? Here, the meaning of conflict is being examined, the experience of facing conflict, as opposed to accepting the abstract word as conclusive.

By using course reflection assignments, I seek to examine phenomenon closely tied to the natural environment of learners and the way they perceive themselves where there are no artificial conditions set, no variables manipulated, and no laboratory involved.

Phenomenology also encompasses the researcher undergoing bracketing, where we remove ourselves from the experience and examine it as an outside observer. The data will be considered as true descriptions of the experience without imposition of researcher bias. Phenomenology is an exploratory approach requiring an open attitude allowing unexpected meanings to emerge.

Data will be collected from the reflections assignments embedded within the Creativity and Innovation course. Data from reflection assignments will be categorized into relevant pieces of the experience captured in the participant's language. Using NVIVO software common meaning units will emerge from the data and will be utilized to describe the experiences and pinpoint variations of the phenomenon.

\section{Surfacing discourses from the students Week 1: Have no expectations}

"I found over the weekend a numerous amount of times where I would assume there was one right answer or one right outcome. After adopting an open mindset I noticed a change in the people around me as well as myself."

"I like the idea of giving and not worrying about what you'll get back." 
insight into the situation or person we are dealing with or we don't fully understand their story."

"My main problem is being too harsh or critical of myself."

"I have to remind myself that I am always learning and investigating new concepts, and that being open to different ideas only makes me a better person."

\section{Week 3: Pay attention}

"It was comforting to reconnect with myself at a deeper lever and remind myself about how far I have come in my 23 years of life. This exercise brought me back down to earth and has helped me regain focus about where I want to go in life."

"l learn more in class when I pay attention!"

"I learned the difference between 'spending time with someone' and 'being with someone.'

\section{Week 4: Ask dumb questions}

"This live-with taught me the importance of understanding problems from differing points of view."

"Sometimes what is obvious to one may not be obvious to another. Everyone is brought up differently with different experiences."

"Don't worry I didn't know that either. Thanks for asking."

\section{Week 5: Do only what you love : Love everything you do.}

"This exercise reminded me of what is important in my life."

"The moral of my story is that we will do a better job if we enjoy or love what we do."

"From scooping ice cream at work to writing reports in school, it's all based on the amount of passion I'm willing to bring forth."

"It is my hope that my life will be a story that I would love to read."

\section{Week 6: Don't worry ... just do it!}

"Worrying! What I noticed is that my thoughts are like a broken record and it usually produces little value."

"We go with the flow around us. I related hard and tough times as the wind, and I was the waves, and when times get rough it represents the wind ... you just have to ride it out, just like the waves in the water. Life keeps moving just like the wind. Go with it."

"Its amazing what can happen when you just jump when you don't want to, but then you start flying ... its like why wasn't I doing this before."

\section{Week 7: See with your heart}

"This week I tried really hard to see with my heart. That means not judging people or situations until I have heard their story."

"l learned small actions can create big changes."

"There is something great about doing things for other people just because."

"Surprisingly, l learned that the more we give, the more we have."

\section{Week 8: Yes or No}

"This live-with taught me how to think for myself."

"This week I have been really listening to my inner voice and intuition and focus on the vision I have set for myself."

"As funny as it may seem, I must have spent more time putting tasks aside then in doing them."

\section{Week 9: Be ordinary}

"For me, being ordinary means being honest with myself. I listen to my inner Self and then know what is right for me."

"I knew when I started reading this live-with that I would struggle with this one! Just like 
everything else I learned in this course, I need to find a happy medium." "I think we need to be true to our self before we can be true to others."

"Everyone wants to stand out or be the person that others follow. What I believe is we should not follow others and try and fit into their shoes but do what we do and be unique which is something ordinary for us on a daily basis."

\section{Week 10: Be yourself. Do your work.}

"To me, if I have to lie about who I am then I am not real."

"This week's live-with was a very difficult one for me. I don't know how to be myself because I seem to have forgotten who I really am in trying to please others. I have work to do." "I always say, be yourself, because each and every one of us has something unique to offer." "I will be looking forward to doing my own weekly exercises to keep the creative juices flowing. I learned a lot about myself through this process and would like to continue to keep growing not only as a business man but also as a person."

\section{What did you learn about yourself?}

"The weekly live-withs have helped me deal and cope with worrying, and I've found myself worrying less and less as the weeks went by. All in all, this course has helped shape me into a better and more suited person for the fast-paced business world."

"I found that the live-withs opened my mind, and let me explore different options and situations which I may, and probably would never have gone out of my way to do." "I believe that the live-withs really helped me. Each week, I either discovered something new about myself or I overcame something that I was struggling with."

"Learning in this class was quite the experience. Every class was something new and full of wonder."

"I like that these thoughts and challenges made me more aware, and gave me a new way to recognize life and my surroundings. I am still working on silencing my voice of judgment which is MUCH better now and I love it and feel much happier and calm because of it." "I now know who I am am. I'm a girl who wants love and respect in her life and relationships. I'm a girl who is going to take her life in her hands, and rock it."

"All these things I learned about myself every week have opened my mind to different things making every choice I decide to make fit in my footsteps and no one else's."

"I am writing my story of the life I want to live with my dreams, my knowledge, my courage, my love, my faith to make every page just as amazing as the last one written. No regrets." "As I come full circle and reflect on all of the past live-withs, I discover how simple and impactful change can be. I am a different person now then I started out at the beginning of this semester and this is all because of a few simple activities I completed every week. I am excited to see what life holds just around the corner now that I feel more empowered than ever before."

"I assumed I knew the best ways to bring out my creativity, but with these exercises I learned some new techniques. I've learned a lot about myself in the past few months and I thank these exercises for that. I now have a better sense of who I am and who I want to be, and I feel more creative than ever."

"Every single live-with made me reflect and think about the future. The live-withs made me think of ideas of how to better myself, and how I want to approach things in the future. These live-withs were really an eye opener. During my college experience, I never had a class where it would let me reflect each week about something different and let me try out new things. Usually I learned everything straight from the textbooks, and lectures. I loved how during the course of these ten weeks, I learned by using life. I got so caught up into lectures, and textbooks, and work, that I lost sense of what really matters, and what I truly care for. I am thankful that I had the opportunity to do all these live-withs, because they all taught me something different. I realized that kind of person I am, what I need to improve, and how I want to approach things in the future." 


\section{Implications}

A number of precepts are emerging and therefore underpin and inform the ongoing development of this study:

1. In an era of deep change and fierce competition for markets and employees; future change agents need to inspire as opposed to motivate. This ability to inspire is determined by integrity of character (who we are, what we stand for, and how we act), realizing an alignment of passion, purpose and the presence of trust.

2. Authenticity and integrity occur when individuals develop self-awareness together with an ability to pay attention to others and the current operating context. This attentiveness enables them to examine a situation from all angles, and communicate a clear vision of what needs to be done.

3. Potential change agents need tools to help them become more reflective and attentive. They need to journey into their own hearts, minds and psyches to discover their core beliefs and perceptual filters to better understand and use the shared myths and stories that can align and inspire an organization to perform beyond the norm.

4. Organizational transformation is achieved one individual at a time. Unless organizations focus on nourishing their human assets as human beings and develop their inner capacity for self-awareness and conscious choice making, old behavioral patterns, which cause resistance to change, will persist.

5. Organizations will not achieve results unless their practices, policies and procedures reflect their espoused values and purpose and unless those values are aligned with those of their employees and other stakeholders.

\section{Potential Benefits:}

1. For the academic community. This study will benefit the academic community by allowing us to better understand AL course delivery within higher education. It will allow us to explore student motivation, engagement and learning.

2. For Participants. The reflective assignments foster deeper learning that leads to personal and professional growth and meaningful personal change.

\section{Research Findings:}

Sheridan College is developing and actively engaging faculty in an Adventure Learning Model. The Sheridan Adventure Learning Model (SAL) is designed to initiate transformative learning experiences through individual and team self-reflexivity, collaborative inquiry-based projects based in a real-world problem and informed by the emerging narrative - changing the trajectory and ending of the current story (Doering, 2006, 2007; Doering \& Veletsianos, 2008); Veletsianos \& Klenathous, 2009; Veletsianos \& Doering, 2010; Koseoglu \& Doering, 2011). Adventure Learning has previously been focused in $\mathrm{K}$ - 12 environments. It is our belief that our SAL will enable the Faculty of Business to provide an enriched educational environment. The objective is to develop student potential by exposing them to complex or 'wicked' challenges that require them to respond with innovative solutions. Our intent is to collapse the space between the classroom and the boardroom. 


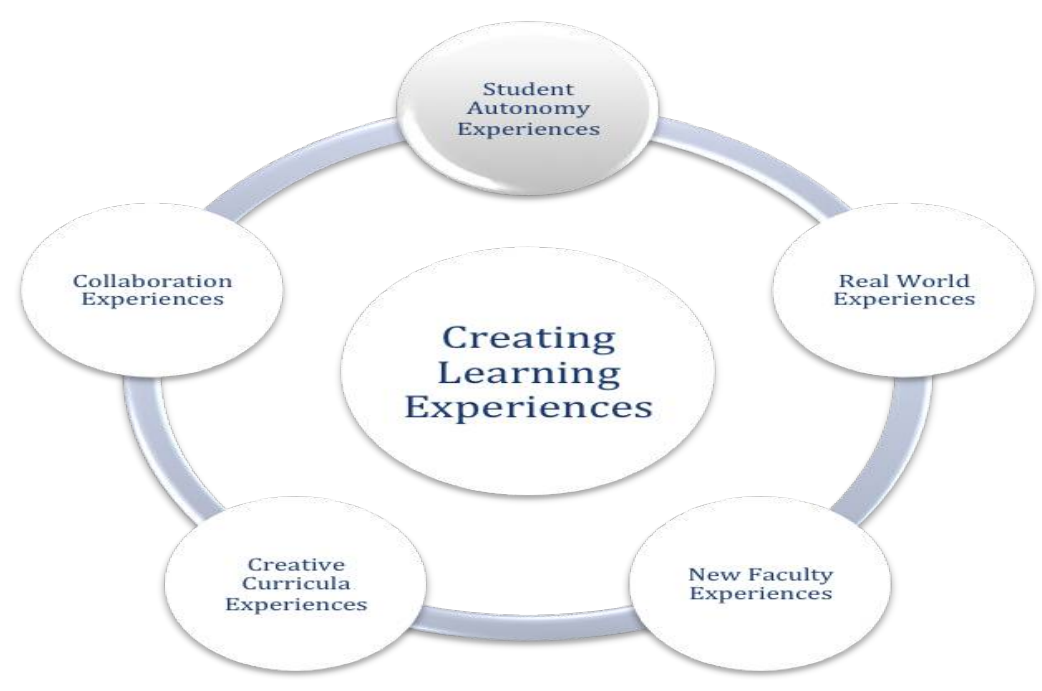

\section{Our Research Questions:}

1. Holding other factors constant, what impact does the AL format have on student success and grade point average (GPA)?

2. What specifically do students, faculty and industry experts like and dislike about the AL model?

a. Which activities and features do students and faculty prefer?

b. How much online instruction do students and faculty prefer?

c. What is the satisfaction of the students and their engagement and emotions towards the AL Mode?

d. What are the factor explaining the satisfaction with $A L$ ?

\section{Conclusions}

In summary, the purpose of this phenomenological study will make an important contribution to higher education teaching and learning scholarship by better understanding how creativity and innovation inform student experiences. This study addresses a gap in the experiential literature by identifying factors that lead to high levels of engagement, motivation and learning. This information will help reveal strategies for instructional design and delivery on how to construct emotionally engaging learning environments that foster deeper experiential learning.

\section{Acknowledgements}

I am grateful for all of the students and executives over the past ten years who have eagerly participated in the experiential 'Creativity in Business' program. To my mentor and founder of the program, Michael Ray (first John G. McCoy-Banc One Corporation Professor of Creativity and Innovation and of Marketing (Emeritus) at Stanford University's Graduate School of Business), thank you for bravely leading the way so that others could follow. To my fellow adventurers in our teacher/trainer group - I thankfully build on your generous and creative spirits. Any mistakes on this path are mine alone.

I also wish to thank my Academic leadership at Sheridan College, Dr. Mary Preece (Provost and VP Academic), Dr. William Holmes (Dean of Business), Dr. Michael Collins (Associate VP Research) and Dr. Darren Lawless (Dean of Applied Research). Without their support and continued encouragement, the current phenomenological study would not be possible. 


\section{REFERENCES}

- $\quad$ Alterio, M. and McDrury, J. (2004). Learning through Storytelling: using reflection and experience in higher education contexts. E-Book: Kogan Page Limited.

- $\quad$ Argyris, C. \& Schon, D. (1974). Theory in Practice: Increasing Professional Effectiveness. San Francisco: Jossey-Bass Inc

- Bates, A.W. and Poole, G. (2003). Effective Teaching with Technology in Higher Education. San Francisco: Jossey-Bass Inc.

-. Beckman, S.L. \& Barry, M. (2009). Design and Innovation through Storytelling. Internationa Journal of Innovation Science. Vol. 1(4): 151-160.

- Black, A. (2010) Gen Y: Who They Are and How They Learn. Educational Horizons, 88(2), p. 92-101.

- Brockbank, A and McGill, I. (2012). Facilitating Reflective Learning: Coaching, Mentoring and Supervision. 2nd Ed. Kogan Page (eBook)

-. Brown, A.D., Gabriel, Y. \& Gherardi, S. (2009). Storytelling and change: an unfolding story. Organization. Vol. 16(3): 324-333.

- $\quad$ Brown, J.S., Denning, S., Groh, K. and Prusak, L. (2004). Storytelling in Organizations: Why Storytelling is Transforming 21st Century Organizations and Management. London: Taylor and Francis.

-. Carr, A. \& Ann, C. (2011). The use and abuse of storytelling in organizations. Journal of Management Development. Vol. 30(3): 236-246.

- Clark, I.D., Trick, D. and Van Loon, R. (2011). Academic Reform: Policy options for improving the quality and cost effectiveness of undergraduate education in Ontario. Kingston: Queen's Policy Studies Series

-. Cutcher, L. (2009). Resisting change from within and without the organization. Journal of Organizational Change Management. Vol 22(3): 275-289.

- Doering, A. (2006). Adventure learning: Transformative hybrid online education. Distance Education, 27 (2), 197-215

- $\quad$---- (2007). Adventure Learning: Situating learning in an authentic context. Innovate, 3(6).

- Doering, A., Riedel, E., Scharber, C., \& Miller, C. (2010). 'Timber for President': Adventure learning and motivation. Journal of Interactive Learning Research, 21(4), 221-251.

- Doering, A., \& Veletsianos, G. (2008). Hybrid online education: Identifying integration models using adventure learning. Journal of Research on Technology in Education, 41(1), p. 101-1.

- Dweck, C.S. (2008). Mindset: the new psychology of success. New York: Ballantine Books.

- Egan, K. (1998). The Educated Mind: How cognitive tools shape our understanding. Chicago: University of Chicago Press

- $\quad$--- (1999). Children's Minds, Talking Rabbits and Clockwork Oranges. Essays on Education. London: The Althouse Press.

- $\quad$--- (2005). An Imaginative Approach To Teaching. San Francisco: Jossey-Bass Inc

-. Flory, M. \& Iglesias, O. (2010). Once upon a time: The role of rhetoric and narratives in management research and practice. Journal of Organizational Change Management. Vol. 23(2): $113-119$

-. Gabriel, Y. (1995). The unmanaged organization: stories, fantasies and subjectivity. Organizational Studies. Vol 16(3): 477-501.

-. George, F. H., \& Voas, J. (2011). Storytelling: From cave art to digital media. IT Professional Magazine, 13(5), 4-7.

- Gobe, M. (2001). Emotional Branding: the new paradigm for connecting brands to people. New York: Allsworth Press.

-. Goldman, E.F. \& Casey, A. (2010). Building a culture that encourages strategic thinking Journal of Leadership \& Organizational Studies. Vol. 17(2): 119-128.

- Grant, G. (2005). ReVisioning the way we work. Bloomington: Trafford Publishing.

- $\quad$---. (2009). Finding your creative core. Bloomington: Trafford Publishing. 
- ---. The drive theory of C.G. Jung: moving ideas to action. International Conference of Jungian Studies. New Orleans, Lousiana, USA. August 2012.

- $\quad$-... Phronetics from the Field: moving ideas to action. World Marketing Congress. Atlanta, Georgia, USA. August 2012.

- Grant, G. and Holmes, B. Effective storytelling in business school ethics curriculum. Managing by Values: Beyond Cultures and Generations Conference. Edmonton: McEwan School of Business International Conference. May 2010.

- Herskovitz, S., \& Crystal, M. (2010). The essential brand persona: Storytelling and branding. The Journal of Business Strategy, 31(3), 21-28.

- John, X. V., Michael, D. P., \& Steven, J. A. (2011). Storytelling: A portal to understanding entrepreneurial organizations. Journal of Marketing Development and Competitiveness. 5(3), 104-109.

- Jones, R. Clarkson, A., Congram, S. and Stratton, N. Editors. (2008). Education and Imagination: post-jungian perspectives. New York: Taylor \& Francis e-Library.

- Koseoglu, S., \& Doering, A. (2011). Understanding complex ecologies: an investigation of student experiences in adventure learning programs. Distance Education, 32(3), p. 339-355.

- Kostera, M. (1995). The narrative collage as research method. Storytelling, Self, Society. Vol 2(2): $5-27$

- Matthews, V. (2008). Generation Z. Personnel Today, p. 48-51.

- McCarthy, J.F. (2008). Short stories at work: storytelling as an Indicator of organizational commitment. Group \& Organization Management. Vol 33(2): 163-193.

- Miller, C., Veletsianos, G., \& Doering, A. (2008). Curriculum at forty below: a phenomenological inquiry of an educator/explorer's experience with adventure learning in the Arctic. Distance Education, 29(3), p. 253-267.

- Moon, J. (2004). Using reflective learning to improve the impact of short courses and workshops. Journal Of Continuing Education In The Health Professions, 24(1), 4-11.

- Oblinger, D. \& Oblinger, J. (2010). Is it age or IT: First steps toward understanding the Net-Generation. In D. Oblinger and J. Oblinger (Eds.), Educating the Net Generation. The Netherlands: Delft University of Technology. Retrieved July 25, 2012, from http://net. educause.edu/ir/library/pdf/pub7101.pdf.

- Ontario Colleges (2011). Student and Graduate Profiles Environmental Scan. Retrieved from: http://www.collegesontario.org/research/2011_environmental_scan/2011_scan_ students.pdf.

- Palmer, P.J. (2007). 10th Ed. The Courage to Teach: exploring the inner landscape of a teacher's life. San Francisco: Jossey-Bass.

- $\quad$ Papert, S. (1980). Mindstorms: Children, Computers and Powerful Ideas. New York: HarperCollins

- Phillips, A. (2012). A Creator's Guide to Transmedia Storytelling: how to capture and engage audiences across multiple platforms. New York: McGraw Hill.

- $\quad$ Pine, B. J. and Gilmore, J.H. (1999). The Experience Economy: work is theatre and every business a stage. Boston: Harvard University Press.

- Ray, M. and Myers, R. (1984). Creativity in Business.

- Ray, M. (2005). The Highest Goal. San Francisco: Berrett-Koehler Publishers.

- Sheridan College (2010). Sheridan: The Creative Campus. Oakville, Ontario.

- Simmons, A. (2007). Whoever tells the best story wins: how to use your own stories to communicate with power and impact. New York: AMACOM.

- Smith, P. (2012). Lead with a Story: A guide to crafting business narratives that captivate, convince and inspire. New York: AMACOM.

- Spoelstra, S. (2009). Organizational brilliance: on blinding visions in organizations. Journal of Organizational Change Management. Vol 22(4): 373-385.

- The Learning Technologies Collaborative (2010). 'Emerging': A re-conceptualization of contemporary technology design and integration. In G. Veletsianos (Ed.), Emerging technologies in distance education. Edmonton, AB: Athabasca University Press. 
- $\quad$ Ulrich, D. \& Brockbank, W. (2007). Dreams: where human resource development is headed to deliver value. Human Resource Development Quarterly.

- Vol. 18(1)

- $\quad$ Volker, J.X., Phillips, M.D. \& Anderson, S.J. (2011). Storytelling: a portal to understanding entrepreneurial organizations. Journal of Marketing Development and Competitiveness. Vol. 5(3): 104-109.

- Vygotsky, L. (1962). Thought and language. (Eugenia Haufmann and Gertrude Vakar, Trans.). Cambridge: MIT Press.

- Wagner, T. (2010). The Global Achievement Gap: why even our best schools don't teach the new survival skills our children need and why. New York: Basic Books.

- $\quad$-- (2012). Creating Innovators: the making of young people who will change the world. New York: Scribner.

- Weimer, M.E. (2010). Inspired College Teaching. San Francisco: Jossey-Bass Publishers.

- $\quad$--- (2013). Learner Centered Teaching. San Francisco: Jossey-Bass Publishers.

- Weizenbaum, J. (1976). Computer Power and Human Reason: From Judgment to Calculation. New York: W.H. Freeman \& Co 